\title{
TERRITÓRIO, DESENVOLVIMENTO E A ECONOMIA DAS \\ GRANDES CIDADES: PERSPECTIVAS DO BRASIL E DA CHINA
}

\section{TERRITORY, DEVELOPMENT AND THE ECONOMY OF LARGE CITIES: PERSPECTIVES OF BRAZIL AND CHINA}

\author{
Marcos Costa Lima* \\ Joyce Helena Ferreira da Silva** \\ João Ricardo Cumarú Silva Alves***
}

\begin{abstract}
As cidades são também transformadores elétricos: elas aumentam as tensões, elas precipitam as trocas, elas agitam sem cessar a vida dos homens.

Elas nasceram da mais antiga, da mais revolucionária das divisões do trabalho: campos de um lado, atividades ditas urbanas de outro ${ }^{1}$.
\end{abstract}

Fernand Braudel

\begin{abstract}
Introdução: refletindo sobre a economia urbana e o lugar das cidades
\end{abstract}

Para se compreender a realidade atual das cidades mundiais, é sempre útil traçar uma perspectiva histórica de seus respectivos processos de crescimento e desenvolvimento. Segundo destacam Brumes (2001) e Barros (2007), é relevante destacar como as cidades surgiram, como elas se organizam, quais suas funções características e suas

\footnotetext{
* Graduado em Philosophie Politique - Université Montpellier - França (1978); mestrado em Sociologia UFPE (1985); doutorado em Ciências Sociais - UNICAMP(1998). Pós-doutorado - Université Paris XIIIVilletaneuse (2003-04). É professor Associado 1 da Universidade Federal de Pernambuco (Recife/PE/Brasil), no Departamento de Ciência Política. marcoscostalima@terra.com.br.

** É doutoranda do Programa de Pós-graduação em Ciência Política da Universidade Federal de Pernambuco (Recife/PE/Brasil) e membro do Núcleo de Estudos e Pesquisas sobre Desenvolvimento e Região (UFPE). Possui mestrado em Ciência Política pela Universidade Federal de Pernambuco e graduação em Ciências Econômicas. joyce.hfs87@gmail.com.

**** É graduando em Ciência Política/Relações Internacionais pela Universidade Federal de Pernambuco UFPE (Recife/PE/Brasil). Membro do Núcleo de Estudos e Pesquisas Regionais e do Desenvolvimento (D \& R).joao_cumaru@hotmail.com.

1. Braudel, Fernand (1967), “Les Villes”. IN: Civilisation materièlle et Capitalisme. Tome Ier, Chapitre 8, p.369:432.
} 
articulações com a estrutura econômica. Nos primórdios, as cidades surgiram como pequenos aglomerados que foram sofrendo transformações ao longo da história.

Singer (1981 apud BRUNES, 2001) defende que a conformação da existência da cidade ocorreu associada às relações entre os cidadãos e os produtores do campo, as quais foram institucionalizadas ao longo do tempo, no intuito de garantir a transferência de mais produtos à cidade. É importante destacar ainda que o que passou a caracterizar os aglomerados humanos na formação do que se convencionou chamar de cidade foi a existência de uma divisão social do trabalho com reflexo nas forças produtivas, impulsionada por "uma massa de consumo" (BRUMES, 2001).

Os povos mais antigos remontam as primeiras organizações análogas a cidades ao período neolítico. Na Antiguidade, a localização das cidades estava ligada às condições naturais do espaço: cidades e civilizações se desenvolveram ao longo de rios como o Rio Amarelo, com a civilização chinesa, e os rios Tigres e Eufrates, com as civilizações mesopotâmicas, região esta considerada o "centro de difusão do fator urbano" à época. "Neste período, prevalecia a cidade com função política, aquela que organizava, dominava, protegia, explorava um território com seus camponeses aldeões, pastores, etc", afirma Brumes (2001, p. 51).

0 esfacelamento do poder central do Império Romano provocou uma "desarticulação da rede urbana construída na
Antiguidade" e, consequentemente, uma perda da importância das cidades no mundo ocidental europeu. 0 período medieval caracterizou-se por uma sociedade excessivamente concentrada em pequenos espaços e em lugares de produção. Para Brumes (2001), estabeleceu-se uma relação entre campo e cidade, com um "sistema urbano aberto", onde o setor econômico passou a gerar a indústria. No segmento social, houve o aparecimento da propriedade de bens móveis e, na área política, surgiu o Estado².

0 renascimento comercial e urbano ao final da Idade Média provocou um retorno ao desenvolvimento das cidades a partir dos centros comerciais, os chamados burgos, associado ao avanço do capitalismo industrial. Do período moderno e contemporâneo em diante, a origem das cidades passa a ser relacionada diretamente à existência de funções urbanas, que podem ser industrial, comercial, cultural, entre outras.

Em uma consistente análise sobre a obra de Fernand Braudel, François Fourquet (1991, p.53) nos diz que "toda economia -mundo aceita um centro, uma região decisiva que dá um impulso às outras e estabelece, apenas para ela, a unidade em pauta". Para Braudel, nos séculos XV e XVI eram as cidades em torno do mediterrâneo, que formavam um quadrilátero que tinha por ângulos Veneza, Milão, Gênova e Florença, que conformavam esse centro. E para construir uma tipologia das economias-mundo, Braudel propõe três regras tendenciais: (i) um espaço que varia lentamente, que não

2. Neste sentido Lefebvre (1972, p.44 apud BRUMES, K.R. Cidades: (Re) Definindo seus papeis ao longo da historia. Revista online Caminhos de Geografia. 2 (3), p.47-56, março/2001) afırma que "os resultados históricos da primeira grande luta de classes e das formas sociais na Europa são as seguintes: cidade contra campo; burguesia contra feudalismo; propriedade de bens móveis/propriedade privada contra propriedade fundiária/comunitária. 
é homogêneo, pois é muito diferenciado em seu interior; (ii) no centro existe uma cidade capitalista dominante, uma e uma só capital-mundo, que está no centro dos acontecimentos, dos circuitos mercantis, do conhecimento, e que consolida toda uma área composta de várias outras cidades que lhe são associadas ou subordinadas; (iii) esse centro estabelece uma hierarquia relacionada com a acumulação de riqueza, e, segundo o historiador, que se configura enquanto uma potência leve, móvel, circulante, capaz de captar fluxos e integrá-los num sistema. E acrescenta ainda que tal centro cria suas regiões secundárias e suas margens exteriores

E embora Braudel admita a primazia econômica, ele aborda esse eco-mundo a partir de várias ordens: a econômica, que gera uma "cadeia de subordinações" comandada por esse centro de capital, que gera trocas desiguais; a política, onde o Estado varia conforme a sua posição central, secundária ou periférica; a ordem da Guerra, que pressupõe o controle dos meios de comunicação mundial; a ordem social, estabelecida a partir da divisão internacional do trabalho, com suas características, a exemplo do trabalho assalariado em Londres e da escravidão nas colônias e, por conseguinte, dos centros de decisão que controlam os setores-chaves da acumulação; e finalmente a ordem cultural, que propaga uma religião dominante, mas também a circulação das letras de câmbio e das tecnologias que florescem no centro. Para Braudel, o capitalismo representa uma "máquina informacional" particular, que são a cidade e a rede de Estados. "Para poder recuperar e fiscalizar os fluxos de atividades estabelecidos pelas cidades, os Estados territoriais tiveram de transformar-se e modificar o modelo despótico asiático e o modelo romano.” (FOURQUET, 1991, p. 62).
0 acúmulo de pobreza nas grandes cidades, mesmo em alguns países de renda elevada, apresenta uma série de impasses que faz da questão urbana um tema proeminente e desafiador para pesquisadores de diversas áreas. No caso dos países subdesenvolvidos, mais do que apêndice indesejável das "ilhas de prosperidade”, a periferia apresenta-se como epicentro de uma dinâmica própria, sendo, ao mesmo tempo, produto reflexivo e elemento ativo de uma lógica maior, completamente funcional dentro do processo de acumulação de capital.

Tomando o exemplo brasileiro, o processo de industrialização e o consequente crescimento das cidades permitiu a consolidação da classe média pari passu, com a criação de uma mão de obra superexplorada nos centros urbanos, mais a formação de um exército industrial de reserva, também de origem rural, que engrossou a parcela de favelados e marginalizados à parte do progresso crescente nas metrópoles. A mesma lógica, portanto, reforçou fenômenos contraditórios e articulados: moderno e arcaico, incluído e marginalizado, central e periférico.

A industrialização dependente, portanto, resultou em um setor com baixa capacidade de absorção de mão de obra. Estes trabalhadores, em geral, estiveram também à margem da esfera de consumo na qual as mercadorias produzidas seriam realizadas. Em outras palavras, diferentemente do modelo capitalista clássico, o modelo periférico e dependente não foi capaz de gerar o trabalhador-consumidor, e este é um fator fundamental na criação de outros mecanismos, não hegemônicos, de suprimento de necessidades.

Tendo em consideração que o crescimento industrial se deu de forma descom- 
passada em relação à infraestrutura e aos requerimentos em serviços, Francisco de Oliveira (1988, p. 33) observa que "a intensidade do crescimento industrial não permitirá uma intensa e simultânea capitalização nos serviços, sob a pena de concorrerem com a indústria propriamente dita pelos escassos fundos disponíveis para a acumulação propriamente capitalística”. Para resolver tal contradição, ocorre o surgimento de uma rede de serviços informais e de um mercado próprio, de características não capitalísticas, fora da zona de interesse dos grandes monopólios multinacionais, para servir a essa população na periferia:

É, sobretudo, nas grandes cidades que a crise vai se localizar. A evidência empírica nos permite falar, no Brasil, de "involução metropolitana”" ${ }^{3}$ devida, em boa parte, à capacidade de atração dos pobres pela metrópole, onde vem engrossar uma demanda de empregos formais e de serviços urbanos que a cidade do capital monopolista não atende. A economia urbana se adapta a essa situação, segmentando-se, através do paralelismo de atividades com os mais diversos niveis de capitalização, tecnologia, organização, e criando oportunidades de trabalho que ali não estariam se apenas existissem as empresas modernas (SANTOS, 1994, p. 73).
A cidade é, então, o grande palco dessas transformações, trazendo, atualmente, como evolução do processo de industrialização, questões de diversas ordens. 0 urbano passa a ter centralidade em um cenário de avanço da especulação imobiliária, de agressão ao meio ambiente, de questionamento do uso do automóvel como alternativa viável de locomoção e, principalmente, de um despertar para a ocupação da cidade como bem público e comum a todos.

Neste último ponto, o espaço urbano passa por um movimento de transmutação, deixando de servir apenas de vitrine para exposição de mercadorias - portanto, o local próprio do consumo - para ser o lugar do convívio, do público, do socializado. Mais do que isso, o urbano deve ser entendido como algo além de um produto concreto de relações econômicas abstratas. Dito de outra forma, a cidade não é só moldada pelo processo de acumulação de capital: trata-se de um lugar de práxis, de ação política transformadora.

0 urbano se revela, tomada sua faceta de concretude do processo de acumulação capitalista, enquanto realização material do capital e pela disposição dessa materialização. Este último aspecto, qual seja, a organização no espaço, manifesta uma noção abstrata de fundamental importân-

3. 0 conceito de "involução metropolitana", conforme indicado por Santos (1994, p. 73), poderia ser identificado, de modo concreto, através da observação dos seguintes indicadores: 1. Crescimento menor do PIB nas metrópoles do que no país como um todo; 2 . Nas regiões onde o capitalismo amadurece, observa-se uma reversão do leque salarial, com algumas ocupações menos bem remuneradas; 3. Alguns indicadores de qualidade de vida passam a ser melhores no interior do que nas Regiões Metropolitanas. Isto é, com o amadurecimento do capitalismo nas metrópoles e, na esteira do mesmo processo, a criação de bolsões de pobreza e crescimento da informalidade, essas regiões passam a apresentar um movimento de involução, que pode ser verificado pela constatação dos fatores colocados pelo autor. Essa involução é parte integrante da evolução do capitalismo nestas áreas mais dinâmicas, como uma unidade de contrários. 
cia: a relação de classes. Dito de outra maneira, a cidade expressa de forma sólida e observável, a luta de classes: áreas nobres e centrais, cuja expressão valorativa não é apenas econômica, mas também social em contraposição à periferia, distante, elemento de dispersão e isolamento da classe trabalhadora.

A observação dos fatores elencados nesta introdução permite que a questão urbana passe a ser estudada a partir de uma apropriação de categorias da Economia Política. É dessa associação que se coloca a necessidade de inclusão do conceito de espaço no contexto do debate marxista, e se trabalha o urbano em uma perspectiva de relativa autonomia conceitual, evitando um possível determinismo econômico sobre o estudo da cidade. Esta última categoria é apreendida como uma instância própria da superestrutura, apresentando, porém, alguma primazia explicativa, de maneira a privilegiar uma relação dialética e não um determinismo causal, direto e unilateral. As diferentes formas de compreensão da cidade como parte componente da superestrutura são, portanto, um dos eixos da discussão.

A noção espacial dentro do marxismo estaria inserida, essencialmente, em um arcabouço conceitual voltado para o entendimento da acumulação e dos movimentos sociais. Mais que isso, assume-se uma relação dialética entre a forma sobre a qual a base econômica (estrutura) ${ }^{4}$ é disposta no espa- ço (superestrutura), tomando os movimentos sociais e os padrões de conflito como consolidados a partir da interação entre o processo de acumulação capitalista e a dinâmica urbana. Doravante, para os fins a que este trabalho se propõe, pretende-se recortar a discussão da questão urbana a partir das contribuições de quatro autores, a saber: Fernand Braudel, Henri Lefebvre, David Harvey e Manuel Castells.

\section{Atualizando Teorias}

Em rompimento com a tradição marxista ortodoxa, Henri Lefebvre considera as relações espaciais como campo para a práxis. Sendo essa uma categoria dotada de autonomia e poder explicativo, o autor rejeita a noção de espaço como mero ambiente construído, afırmando que "o espaço e a política do espaço 'exprimem' as relações sociais, mas reagem sobre elas. Bem entendido, se há uma realidade urbana que se afirma e se confirma como dominante, isso só se dá através da problemática urbana." (LEFEBVRE, 1999, p. 26-27, grifo nosso).

Trata-se, portanto, do urbano como elemento ativo, força de produção e lugar de luta política. Nesse contexto, retira-se a centralidade da acumulação capitalista como elemento basilar da modernidade e traz-se à tona a questão urbana como a grande problemática pós-industrial. Nesse ponto, Lefebvre reconhece o fenômeno urbano como componente superestrutural

4. Conforme define Marx (2008, p. 47) no prefácio da Contribuição à Crítica da Economia Política: "Na produção social da própria existência, os homens entram em relações determinadas, necessárias, independentes de sua vontade; essas relações de produção correspondem a um grau determinado de desenvolvimento de suas forças produtivas materiais. A totalidade dessas relações de produção constitui a estrutura econômica da sociedade, a base real sobre a qual se eleva uma superestrutura jurídica e política e à qual correspondem formas sociais determinadas de consciência. 0 modo de produção da vida material condiciona o processo de vida social, política e intelectual”. 
sem, contudo, imobilizá-lo ou deixá-lo estático como elemento reflexivo do modo de produção capitalista. Entende-se a dinâmica urbana em uma relação dialética com o modo de produção:

A problemática urbana impõe-se à escala mundial. Pode-se definir a realidade urbana como uma "superestrutura", na superfície da estrutura econômica, capitalista ou socialista? Como um simples resultado do crescimento e das relações de produção? Não! A realidade urbana modifica as relações de produção sem, aliás, ser suficiente para transformá-las. (LEFEBVRE, 1999, p. 26)

A partir deste raciocínio, o espaço se torna parte do processo produtivo, se faz relação social e torna concretas as relações de propriedade e, consequentemente, de classe. Exprime valor de uso e valor de troca. A cidade é, então, o locus onde está estruturado um complexo sistema de valores que cumpre, segundo Lefebvre, uma função fundamental na lógica de acumulação capitalista.

É nesse contexto que o sociólogo francês compreende o urbanismo como um urbanismo de classe. Considerando que o espaço é portador de valor de uso e valor de troca, Lefebvre argumenta que, ao adquirir um volume habitável, o valor de uso se expressa não apenas pela utilidade daquele espaço, por ser um "suporte material do valor de troca” (MARX, 2013, p. 114), mas, também, por estar carregado de uma significação social, traduzindo-se em um signo de prestígio e poder, ou de ausência deles. Isso ocorre por ser a disposição no espaço uma forma de materialização da relação de classes, uma vez que a distância do centro, os bairros nobres e a periferia são indicadores do lugar do individuo na estratificação social.
Se Lefebvre relativiza o modo de produção da vida material como definidor, em última instância, das demais formas sociais - especificamente, do fenômeno urbano -, é por entender a produção do espaço como elemento condutor de aspectos da prática. Sob esta ótica, ainda que a questão urbana não tenha primazia sobre o modo de produção, a cidade teria condições de modificar algumas variáveis econômicas dentro da sua lógica de auto-organização e de concentração de relações sociais diversas capazes de gerar mecanismos de resistência. As relações espaciais oferecem o lugar para a ação transformadora, sendo a cidade um dos atores mais relevantes da sociedade pós-industrial.

É nesse patamar que toma forma o que Lefebvre denomina "racionalidade urbana": arranjo sucessor de outros tipos de racionalidade precedentes, e que deve suplantar a racionalidade industrial. A questão urbana se sobressai, substituindo a sociedade industrial, ou seja, a industrialização se torna subordinada à urbanização. A prática dessa racionalidade se verifica a partir do que o autor concebe como "revolução urbana":

Utilizando-se as palavras "revolução urbana”, designaremos o conjunto das transformações que a sociedade contemporânea atravessa para passar do período em que predominam as questões de crescimento e industrialização (modelo, planificação, programação) ao período no qual a problemática urbana prevalecerá decisivamente, em que a busca das soluções e das modalidades próprias à sociedade urbana passará ao primeiro plano. (LEFEBVRE, 1999, p. 19)

Em seu esquema, Lefebvre traça um eixo temporal que baliza a relação dialética entre os diversos modelos de cidades em uma lógica evolucionista, de acordo 
com a prevalência de determinadas características, sejam elas políticas ou do modo de produção. 0 ponto de partida é a cidade política que, segundo Lefebvre (1999, p.21) "acompanha, ou segue de perto, o estabelecimento de uma vida social organizada, da agricultura e da aldeia”. Seria o lugar do estabelecimento da administração, dos tributos, da ordem e do poder. 0 crescimento das trocas e das atividades mercantis permite que a cidade comercial suceda a organização anterior, sendo produtora de uma transformação essencial para a consolidação da forma posterior, a saber, a inflexão do agrário para o urbano - produto e produtora da cidade industrial.

Marx, já em seus escritos de juventude, entendia que a oposição entre a cidade e o campo começava com a passagem da barbárie à civilização, do regime de tribos ao Estado, da localidade à nação, processo esse que ocorreu em toda a história do universo, até os nossos dias. A reflexão merece ampla qualificação, pois aponta uma trajetória inexorável, com o urbano representando o avanço, a modernidade, e isso não tem sido, necessariamente, uma lei.

Ao revelar o crescimento da concentração urbana, o êxodo rural, a extensão do tecido urbano e uma completa sujeição do agrário pelo urbano, a cidade industrial é portadora, como todas as anteriores, das contradições que vão originar uma nova forma de organização e, com isso, uma racionalidade própria. Para utilizar as categorias de Lefebvre (1999), a cidade industrial e suas relações sociais conduziriam a uma fase crítica, que pode ser sucedida por um momento em que o fenômeno urbano torna-se proeminente, conforme a hipótese apresentada pelo autor.

0 modo de produção seria superado pelo urbanismo, pela sociedade urbana que, no pensamento de Lefebvre (1999, p. 16), "designa, mais que um fato consumado, a tendência, a orientação, a virtualidade”. 0 objetivismo de classe seria substituído por um subjetivismo de classe, o espaço se transmutaria de uma mera construção do processo de acumulação capitalista em um ator chave, capaz de reagir às determinações das forças produtivas. As ideias de Lefebvre, entretanto, não estiveram isentas de reparos ou críticas. Para os propósitos desta exposição, serão apresentadas algumas apreciações de David Harvey e Manuel Castells sobre o trabalho de Lefebvre, e posteriormente serão exibidas as abordagens individuais dos respectivos autores.

Para Harvey, o equívoco de Lefebvre estaria, principalmente, em minimizar o modo de produção capitalista, subordinando-o ao fenômeno urbano. A hipótese da sociedade urbana que submete a sociedade industrial estaria, portanto, assentada em uma dialética metafísica: o esquema de Lefebvre apresentaria um dever-ser, ou um conjunto de fundamentos de uma possível forma de organização social, sem a correspondente verificação empírica. Segundo o geógrafo britânico, de modo concreto, a questão urbana permanece imersa, integrada e articulada com a lógica de reprodução do capital. Dessa forma, de acordo com Harvey (1973 apud KATZNELSON, 2004, p. 99, tradução nossa) “a urbanização proporciona a oportunidade para o capital industrial dispor dos produtos que cria. Neste sentido, o processo de urbanização ainda está sendo impulsionado pelas exigências do capitalismo industrial".

As objeções de Harvey e Castells a Henri Lefebvre podem ser melhor visualizadas quando se considera que os dois primeiros se propõem a estudar o fenômeno urbano a partir de uma aplicação algo rigorosa do 
método marxista para, então, gerar uma nova perspectiva teórica sobre a cidade, através da redefinição da questão urbana e de verificação empírica. Lefebvre, conforme exposto, resiste à noção de que a acumulação capitalista permanece como variável central na explicação dos problemas da sociedade pós-industrial, fazendo emergir uma nova peça como pilar da modernidade em sua abordagem - o urbanismo. Para Harvey e Castells, a preocupação de Lefebvre estaria na criação de uma utopia e de alguns mecanismos para a prática política pela via urbana, o que levaria o autor a negligenciar aspectos fundamentais dos processos sociais.

Em seu livro, Social Justice and the City, Harvey (1993) define urbanismo como uma construção, uma forma particular ou um padrão consolidado a partir de um processo social. Segundo ele, o modo de produção se manifesta em um ambiente espacialmente estruturado, produto da ação do homem. A cidade seria, então, o ambiente edificado, a instância em que fenômenos sociais tornam-se tangíveis, o abstrato torna-se concreto. A cidade e o urbanismo cumpririam seu papel, como partes componentes da superestrutura, de estabilizar um determinado modo de produção.

A cidade é, em parte, um depósito de ativos fixos acumulados da produção anterior. É construída por uma dada tecnologia e no contexto de um dado modo de produção (o que não quer dizer que todos os aspectos da construção da cidade são funcionais em relação ao modo de produção). (HARVEY, 1993, p. 203)

De modo geral, a produção, circulação e realização das mercadorias, bem como a apropriação de mais-valia, na perspectiva de Harvey, permanecem reguladas pelas condições derivadas da sociedade industrial. As formulações do autor trazem, portanto, como preocupação central, as conexões entre fenômenos espaciais e modos de produção. Se o sistema capitalista para Harvey, é o elemento que molda o espaço urbano, para Castells o elemento fundamental é a necessidade de reprodução da oferta de trabalho.

A característica que define a cidade, no pensamento de Manuel Castells, é o uso do espaço e de suas relações sociais no processo de reprodução da força de trabalho, que engendra o modo de produção capitalista. Por esta perspectiva, a problemática urbana seria intrínseca à industrial e a problemática espacial estaria na órbita do fenômeno social. 0 autor aceita a cronologia histórica do esquema de Lefebvre, estando em acordo com a centralidade do urbano como arena de conflitos e de transformações. Entretanto, Castells considera que o sociólogo francês negligenciou alguns aspectos próprios dos processos sociais, limitando a questão urbana ao urbanismo e minimizando as contradições inerentes ao capitalismo no que ele considera ser a sociedade pós -industrial.

Cidades, como toda realidade social, são produtos históricos, não só na materialidade física, mas em seu significado cultural, no papel que desempenham na organização social e na vida das pessoas. A dimensão fundamental na mudança urbana é o conflitivo debate social entre as classes e atores históricos sobre o significado do urbano, o significado das formas espaciais nas estruturas sociais, $\mathrm{e}$ o conteúdo, a hierarquia e destino das cidades em relação à estrutura social como um todo. A cidade (e cada tipo de cidade) é o que uma sociedade histórica decide o que ela será [...] Por isso, definimos a forma urbana pelo 
significado simbólico do sentido social e das superposições dos sentidos históricos do urbano (e de suas formas) sempre determinada por entre um processo conflitivo entre atores históricos. (CASTELLS, 1983 apud KATZNELSON, 2004, p. 135) ${ }^{5}$

Considerando que a cidade seria um domínio de consumo, reprodução e ação coletiva, influenciado pelo marxismo althusseriano, Castells destaca o componente ideológico em sua análise da ação coletiva na criação de formas urbanas. 0 Estado e seu aparato regulariam a lógica urbana exercendo os interesses da classe dominante, e essa intervenção, tanto do ponto de vista das unidades de produção quanto de consumo, refletiria ou seria a fonte principal do modo de vida urbano. Tal fenômeno, entretanto, não estaria isento de eventuais crises envolvendo os mais diversos segmentos sociais, e essas descontinuidades, segundo o autor, encontrariam duas possíveis soluções: reformismo ou revolução.

Acreditamos que esta interpretação dicotômica não vem correspondendo aos processos sociais em curso. Nem no meio urbano, nem no meio rural. De todo modo, são perspectivas teóricas que nos auxiliam e nos chamam a atenção para um conjunto de fatores presentes nos processos urbanos da atualidade, para as contradições inerentes a esses processos, e que nos obrigam a refinar os instrumentos de análise para chegarmos mais perto das transformações urbanas. Sob o influxo dessas abordagens teóricas de espectro mais geral, partiremos para observar mais de perto os processos de urbanização das grandes metrópoles na China e no Brasil, buscando as especificidades inerentes de cada processo e, se é possível indicar pro- ximidades e distanciamentos, assimetrias e semelhanças nos dois casos.

\section{As transformações do espaço urbano na China}

Desde 1949, o tamanho de distribuição das cidades na China tem mudado e, segundo Zhou, Shangyi; Daí, Juncheg e Bu Jiahua (2013), o divisor de águas foi 1978. 0 papel do governo foi decisivo. Primeiro, com a ampliação da vitalidade econômica pela implantação de uma nova estratégia de desenvolvimento regional. Em segundo lugar, promovendo o desenvolvimento de cidades consideradas atrasadas ou em declínio pelas transferências governamentais, via políticas fiscais. Consequentemente, metrópoles e grandes cidades não cresceram anormalmente no processo de globalização da urbanização chinesa.

Estudos sobre cidades podem ser divididos em duas categorias: (i) aqueles que focam sobre o tamanho de uma cidade individual; (ii) os que destacam a distribuição e o relacionamento de uma grande cidade e as pequenas cidades numa determinada região.

0 estudo de Zhou, Shangyi et al (2013) analisa o papel que desempenha o Estado (governo central), desde 1949, para criar e definir o tamanho da distribuição das cidades na China.

As grandes cidades se desenvolveram rapidamente após a revolução industrial por conta da aglomeração dos fatores de produção. Posteriormente, as cidades médias entraram em processo de rápido crescimento devido aos efeitos marginais que acabaram recebendo, por exemplo, a partir do alto custo de produção dos fatores - água, transporte e estradas que precisam 
buscar novos locais atrativos fora das áreas metropolitanas.

Paul Bairoch (1988) afırma que as mudanças globais na distribuição do tamanho das cidades ocorreram entre 1910 e 1980 . Ele observa que, independente do número de cidades ou da população, o crescimento das grandes cidades é muito mais marcado do que aquele das cidades pequenas e médias. Comparando o número de cidades em 1800, as grandes cidades cresceram 60 vezes, enquanto as pequenas e médias, apenas 18 vezes. Com relação à população, as grandes cidades cresceram 106 vezes, enquanto as pequenas e médias, apenas 18 vezes.

Pode-se, para efeito de qualificação, definir grandes cidades em: (i) metrópoles (acima de 10 milhões de habitantes); (ii) megalópoles (entre 5 e 10 milhões); (iii) grandes cidades (entre 1 e 5 milhões); (iv) cidades médias (entre 500.000 e 1 milhão) e (v) cidades pequenas (até 500 mil). Por certo, há uma arbitrariedade nestes cortes e critérios, pois outra forma de classificar as cidades é pelos graus de funcionalidade que estabelecem em determinado território ou região, porquanto uma cidade média em um território de escassas metrópoles pode exercer uma atração e uma rede de articulações extremamente importantes para as demais no entorno.

No caso da China, as 100 maiores cidades - listadas por PIB per capita em 2011 - estão na faixa das grandes cidades. Estas estão praticamente distribuídas nas zonas costeiras do País - o delta do Rio das Pérolas, o delta do Yangtsé e a borda do Bohai. Isso demonstra os benefícios para sua aglomeração populacional, sobretudo no que diz respeito ao custo das infraestruturas. Contudo, a taxa de crescimento do PIB das grandes cidades na China está abaixo, se comparada à média nacional urbana,,o que significa que, no futuro próximo, a taxa de investimento nas grandes cidades tenderá a cair.

Stiglitz (2010) comenta que a China é o maior estado keynesiano em escala mundial, onde as intervenções acontecem em muitas formas. Contudo, as políticas de intervenção na urbanização na China diferiram daquelas praticadas no Ocidente (ver Li e Liu, 2011).

Os períodos de urbanização na China após a Segunda Guerra Mundial podem ser estabelecidos em dois: o primeiro, de 1949 a 1978, de crescimento instável; e o segundo, de 1978 a 2014, de crescimento estável. 0 segundo período pode também ser dividido em duas fases: (i) de 1978 a 1990, e (ii) de 1990 a 2014 . Nesta última fase, o governo teve um papel bem mais acentuado. 0 governo central preferiu usar instrumentos fiscais para influenciar a urbanização e também ampliar a atração das grandes cidades como um repositório de trabalho, o que, em certa medida rompeu as restrições estabelecidas pelo sistema hukou, que realiza o controle endógeno das migrações no país. 0 desenvolvimento das pequenas cidades na China aconteceu rapidamente após 1990, de maneira contrária ao que acontecia nas grandes cidades, que ainda se beneficiavam de economias de escala.

A fim de lidar com a diversidade interna, o governo central passou a introduzir políticas para controlar o número de grandes cidades e também a promover as cidades de porte médio, aquelas que apresentavam vantagens competitivas mais acentuadas. Para Gu et al (2012), os mecanismos de urbanização da China incluem não apenas o conjunto de diferentes fatores, como a modernização e a reestruturação industrial sob uma perspectiva ocidental, mas também os ambientes de políticas específicas das di- 
ferentes fases de desenvolvimento do país.

As reformas da terra e da moradia que ocorreram depois de 1978 tiveram um significativo impacto sobre a distribuição dos tamanhos de cidades na China. A reforma da terra teve impacto positivo no aumento da receita do governo para financiar os enormes projetos de infraestrutura e de oferta de serviços públicos que interferem na ampliação das cidades. A contraparte negativa foi o desenvolvimento desbalanceado no tamanho diferenciado de cidades. A reforma da moradia também foi um fator crucial para o desenvolvimento, especialmente para as ondas de migração intercidades.

Tabela 1 - Evolução quantitativa da distribuição do tamanho de cidades na China

$\begin{array}{llllllllllll}\text { Tamanho do } & 1949 & 1957 & 1965 & 1978 & 1985 & 1988 & 1990 & 1995 & 2000 & 2005 & 2010 \\ \text { assentamento urbano } & - & - & - & - & - & - & - & - & 1 & 3 & 3 \\ \begin{array}{l}10 \text { milhões ou } \\ +5 / 10 \text { milhões }\end{array} & - & 1 & 1 & 1 & 3 & 3 & 3 & 5 & 5 & 6 & 9 \\ \begin{array}{l}1 / 5 \text { milhões } \\ \text { 500.000 a 1 milhão }\end{array} & 8 & 12 & 14 & 27 & 39 & 41 & 64 & 74 & 84 & 104 & 113 \\ \end{array}$

O período 1949-1988 foi extraído de 50 anos das novas cidades chinesas (State Statistical Bureau, 2000). Os dados para o período desde 1999 são do Anuário estatístico das cidades chinesas (State Statistical Bureau, 2000-2011). 0 tamanho das cidades é medido pela população da área urbana ao final do ano, e não inclui a população de sua área rural.

No Gráfico 1, verifica-se que justamente no ano de 2014 a população chinesa que vive no meio urbano equivale à população rural, ao mesmo tempo em que se aponta a tendência de declínio, por um lado, da po- pulação rural e, por outro, do crescimento urbano no período de 1950 a 2030 . Um comentário adicional é que o início da mudança mais radical se deu nos anos 1980.

\section{Gráfico 1 - População urbana e rural na China entre 1950 e 2030}

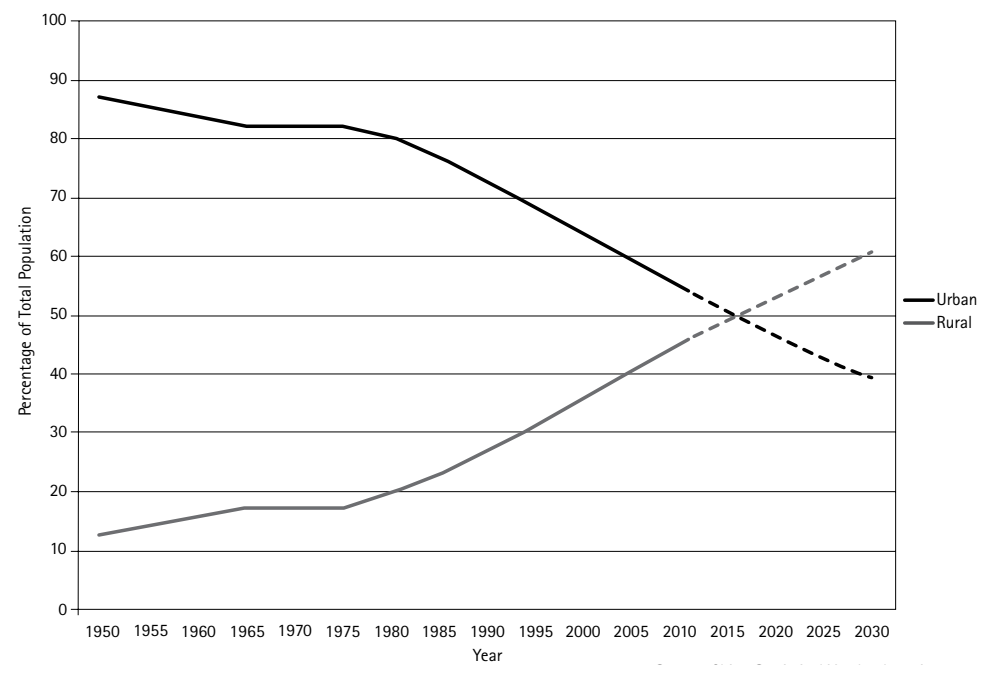


- 1980s: Focus on coastal areas "Open" cities, Special Economic Zones

- 1990s: Attention shifts inland, "Go West" program

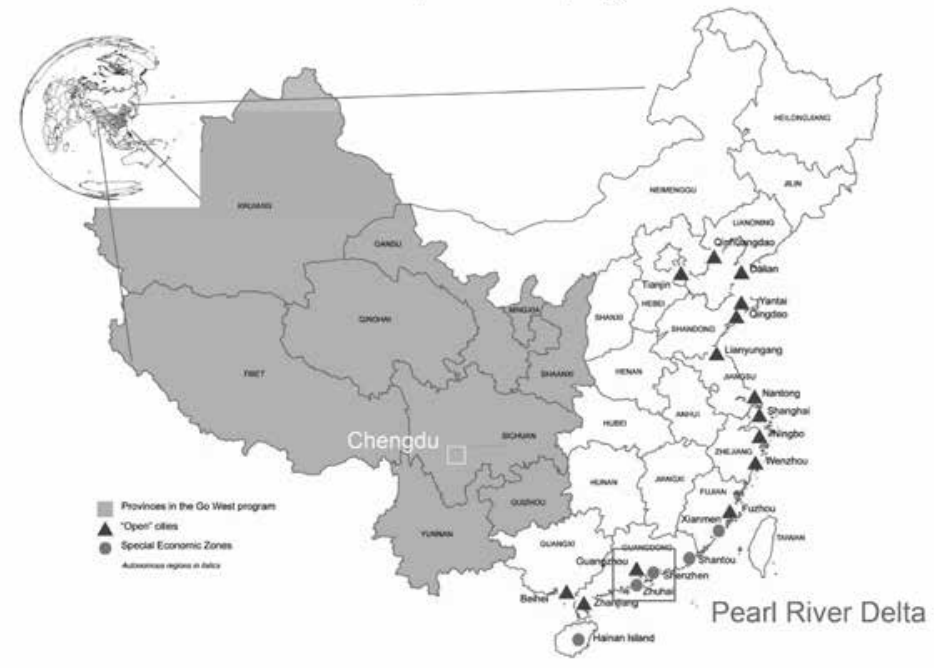

Anos 1980: Foco nas áreas costeiras - "Cidades Abertas", Zonas Econômicas Especiais.

Anos 1990: Mudança de foco para o interior, programa "Ir para o Oeste".

No mapa, os triângulos em vermelho apresentam as "cidades abertas" e, as bolas em laranja, as Zonas Econômicas Especiais. A ampla área em cinza o mostra o programa focado na região Oeste da China.

A China tem experimentado um processo de urbanização muito acelerado desde 1980, com o desenvolvimento de um grande número de cidades. Isso é muito diferente do processo de crescimento estável das cidades na maioria dos países, onde o principal canal de crescimento urbano é a expansão das cidades já existentes, muito mais do que o nascimento de novas zonas urbanas.

Existem três diferentes níveis administrativos de cidades no sistema urbano chinês: municipalidades (ou províncias), prefeituras e condados. Os pequenos vilarejos ou assentamentos com níveis administrativos mais baixos não são tratados como cidades. 0 critério mais importante distinguindo cidades, vilas e lugares rurais é a escala da população urbana. Em particular, existe uma fronteira para uma aglomeração ser considerada enquanto cidade. A impor- tância econômica e a política da aglomeração urbana é também levada em consideração. Contudo, a definição de cidades tem sido consistente desde 1949, quando a República Popular da China foi estabelecida.

0 gráfico a seguir apresenta a evolução da confıguração da distribuição da população urbana na China. Aparecem então três estágios de crescimento de cidade, onde o primeiro é aquele de 1949 a 1961, o segundo é um estágio que aponta uma estagnação e que vai de 1961 a 1978 e o terceiro indica uma rápida expansão que coincide com as reformas econômicas que se iniciam em 1978 (ANDERSON e GE, 2005). Vê-se que as cidades com menos de 500 mil habitantes eram 65\% em 1950 (em azul); aquelas de 500 mil a 1 milhão de habitantes (em vermelho) representavam uma fatia de 10,9\% em 1950 e cresceram para 14\% em 2010. As 
cidades com entre 1 e 5 milhões (em verde) passam de 18,2\% em 1960 e atingem 23\% em 2010. Mas o fato mais radical é o surgi- mento, sobretudo a partir do final dos anos 1990, de três cidades com mais de 10 milhões de habitantes (em azul claro).

Gráfico 2 - Evolução da distribuição do tamanho da população urbana da China

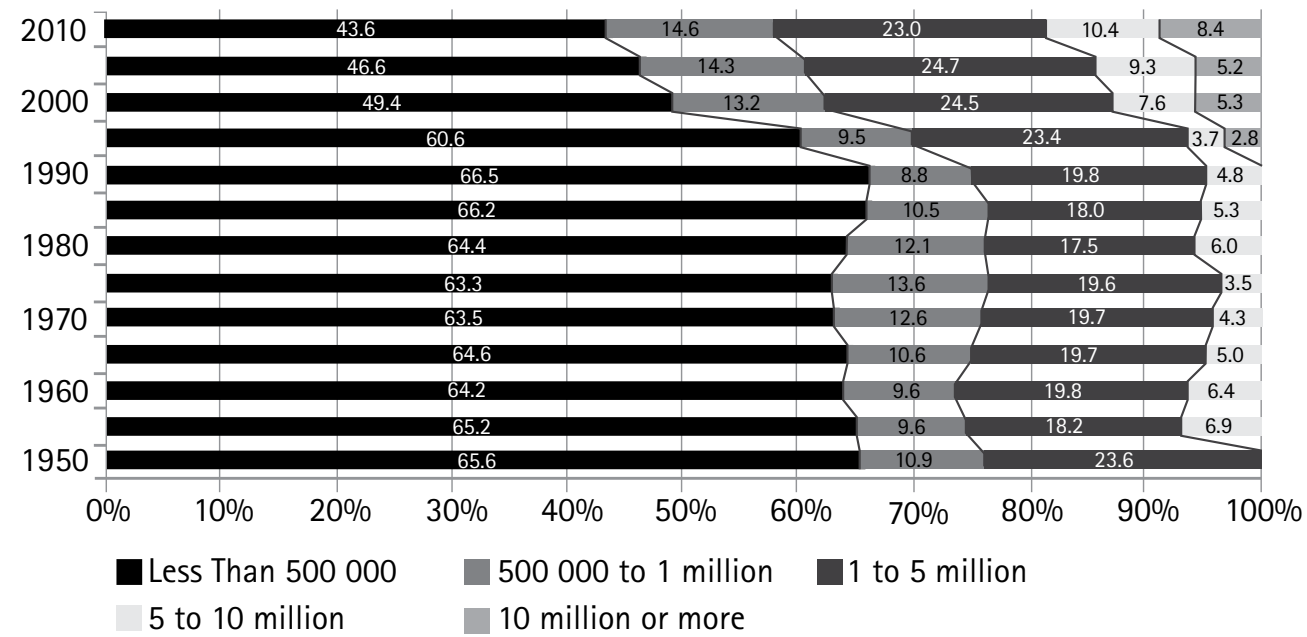

(Censos de 1953, 1964, 1982, 1990, 2000 e 2010. Estimativas para 1965, 1970,1972,1997 e 2005 de acordo com Divisão da População, Perspectivas da Urbanização Mundial: Reedição revista pelas Nações Unidas. Departamento de Economia e assuntos Sociais

0 quadro a seguir é importante, pois apresenta como era em 2010 o cenário das atuais megalópoles da China, com respectivo produto interno bruto. São, ao todo, treze cidades, a maioria delas perfazendo amplas regiões metropolitanas. Após a leitura do Quadro 1, apresentamos um mapa do Delta do Rio das Pérolas, uma das regiões mais populosas da China, onde indicamos, como exemplo, a conurbação Guangzhou-FoshanZhaoqing, que possui um total de 10,8 milhões de habitantes e representa o terceiro
PIB chinês. Esse conglomerado não considera a região rural. Segundo o censo de 2010, a área administrativa da cidade tem uma população de 12,78 milhões, o que a faz a mais populosa cidade do Sul da China. Se somarmos Guangzhou (Cantão) a Foshan (7,19 milhões), ter-se-á uma ideia da dimensão dessa região metropolitana, que fica a apenas 120 km de Hong-Kong. Estima-se que a população total das chamadas megacidades situadas no delta do Rio das Pérolas alcança mais de 40 milhões de pessoas. 
Quadro 1 - Instantâneo das megalópoles chinesas

\begin{tabular}{llcr}
\hline & Sub-cities & Population* (m) & GDP** (Rmb bn) \\
Chang-Zhu-Tan & Changsha, Zhuzhou, Xiangtan & 8.3 & 320 \\
Chengdu & Chengdu & 8.4 & 313 \\
Chongqing & Chongqing & 9.2 & 489 \\
Greater Beijing & Beijing, Tianjin & 23.3 & 1,900 \\
Greater Shanghai & Shanghai, Suzhou & 18.2 & 1,787 \\
Greater Xi'an & Xi'an, Xianyang & 7.9 & 264 \\
Greater Zhengzhou & Zhengzhou, Kaifeng & 7.6 & 162 \\
Greater Guangzhou & Guangzhou, Foshan, Zhaoqing & 10.8 & 1,356 \\
Hefei economic circle & Heifei, Lu'na, Huainan, Chaohu & 7.2 & 222 \\
Shandong peninsula & Qingdao, Yantai, Weihai, Rizhao, & 17.9 & 1,227 \\
& Weifang, Jinan, Binzhou, Dongying, Zibo & & \\
Greater Shenyang & Shenyang, Anshan, Fushun, Yingkou, & 11.0 & 668 \\
Shenzhen & Benxi, Liaoyang, Tieling & & \\
Wuhan & Shenzhen & 11.1 & 820 \\
\hline
\end{tabular}

Source: Economist Intelligence Unit, National Bureau of Statistics.

* 2010 estimates, metropolitan area

* 2009 figures, metropolitan area

0 foco inicial das políticas de porta-aberta em 1980 foi a abertura de quatro zonas econômicas especiais (SEZs), seguida pela ampliação de 14 cidades nas zonas costeiras
(COCs). No princípio de 1990, a China aprofundou as reformas econômicas por meio da redução das restrições dos investimentos estrangeiros, com a posterior redução de tarifas, e a abertura dos mercados domésticos.

Mapa 2 - Cidades em torno do Delta do Rio das Pérolas

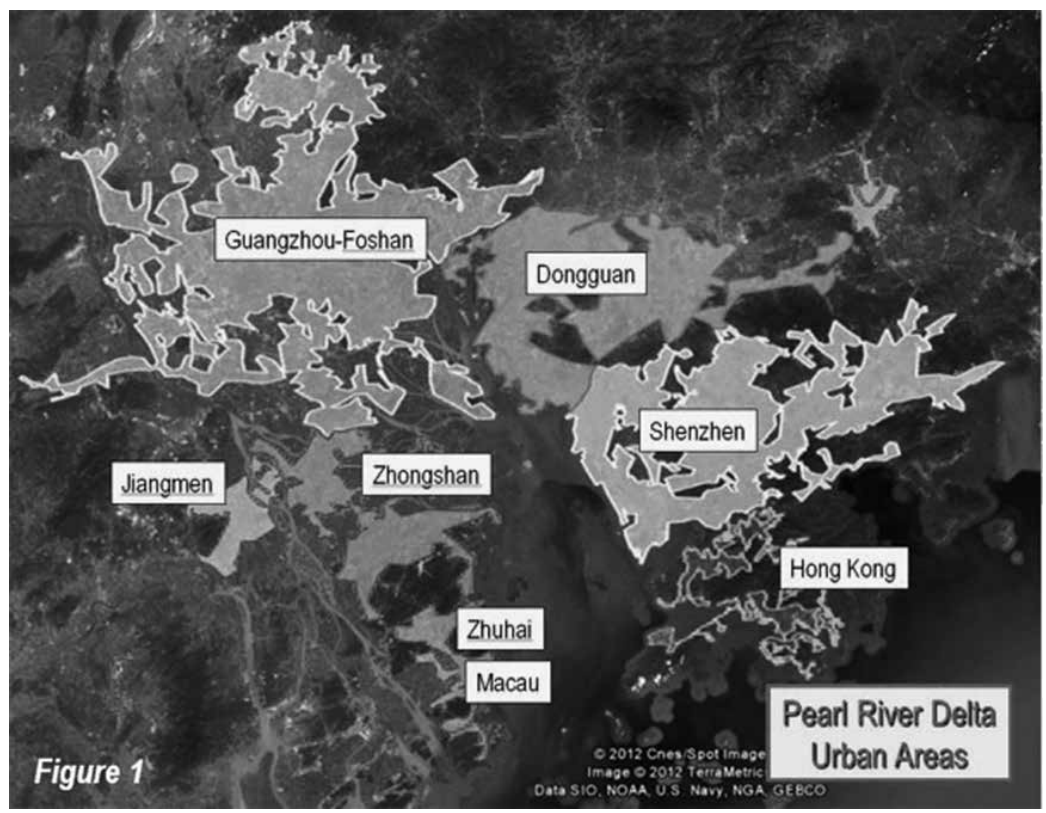




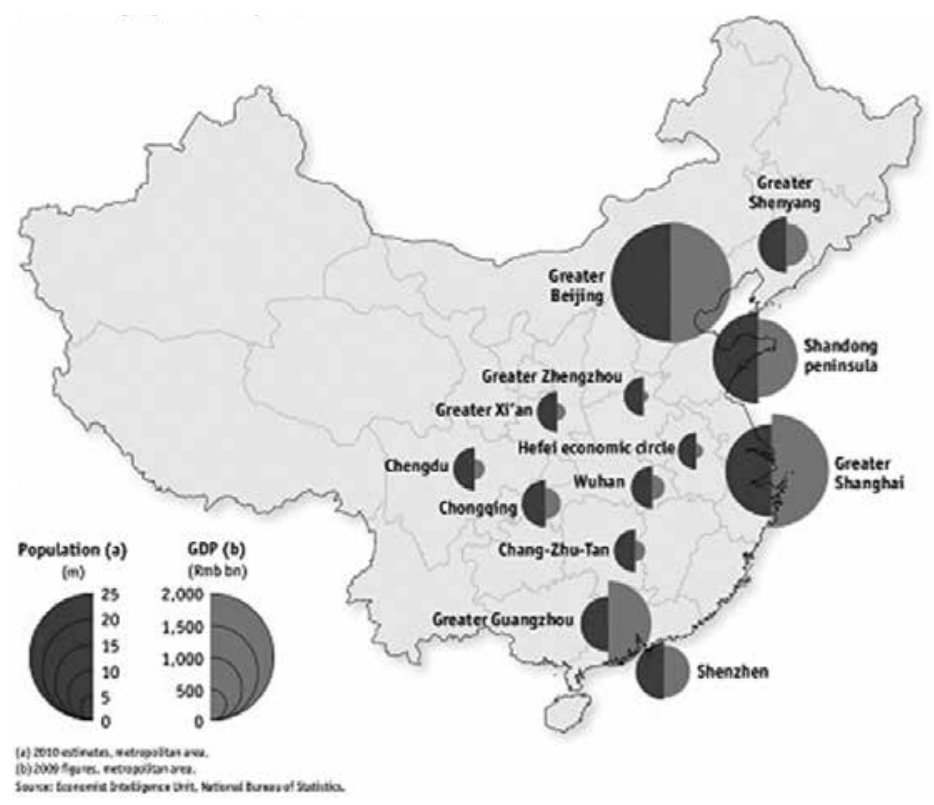

$\mathrm{Na}$ sequência de mapas a seguir, fica e o fenômeno da metropolização chinesa, muito patente o adensamento das cidades principalmente a partir de 1990.

Mapa 4 - Evolução do adensamento das cidades na China: 1949-2010

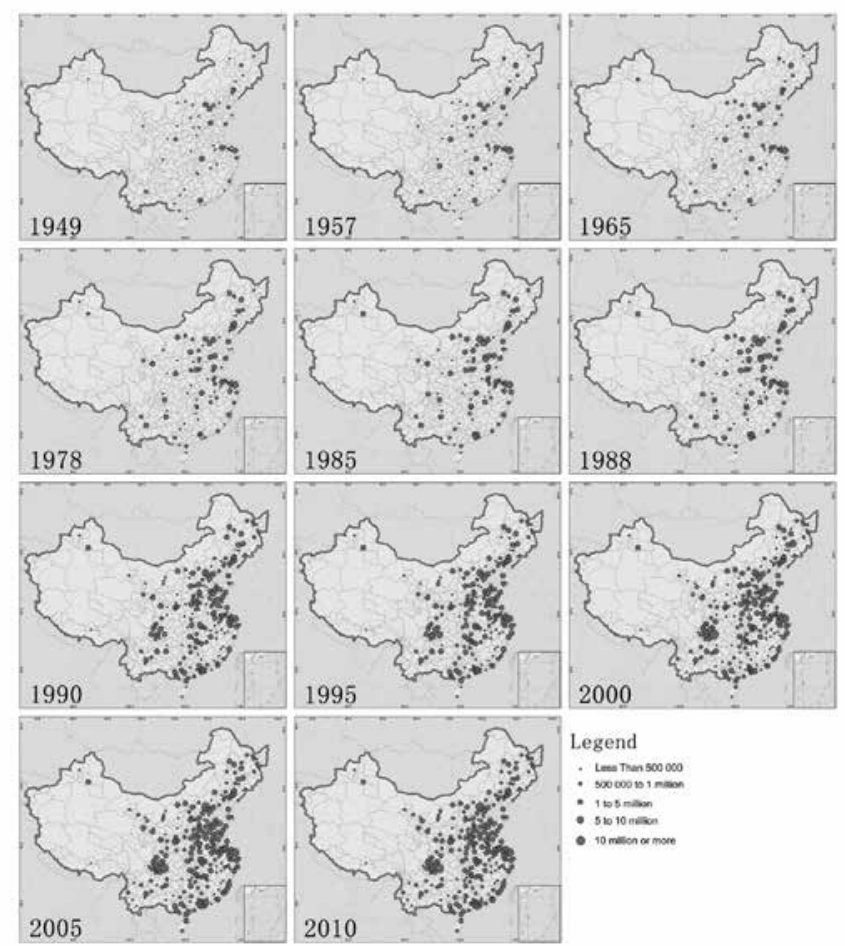


As cidades consideradas pequenas ou de porte médio, muitas situadas em áreas tidas como atrasadas, são incapazes de atrair investimentos e mão de obra, seja devido à baixa capacidade fiscal local, seja por uma fragilidade em prover bens públicos de qualidade - o que impede que se desenvolvam. As transferências governamentais poderiam e deveriam promover o desenvolvimento destas áreas. É o que parece estar sendo planejado recentemente, com os projetos de desenvolvimento para o oeste do país, que têm a ver também com o novo ciclo chinês de não se garantir apenas com as exportações das zonas preferenciais, mas de buscar uma espacialização endógena das políticas de desenvolvimento.

No Mapa 5, que apresenta a posição das 10 maiores cidades chinesas, distribuídas por áreas geográficas, verifica-se que o desenvolvimento das megalópoles tem se dado sobretudo na região Leste e costeira do país, com duas grandes megalópoles no início da região Oeste e duas na região Central.

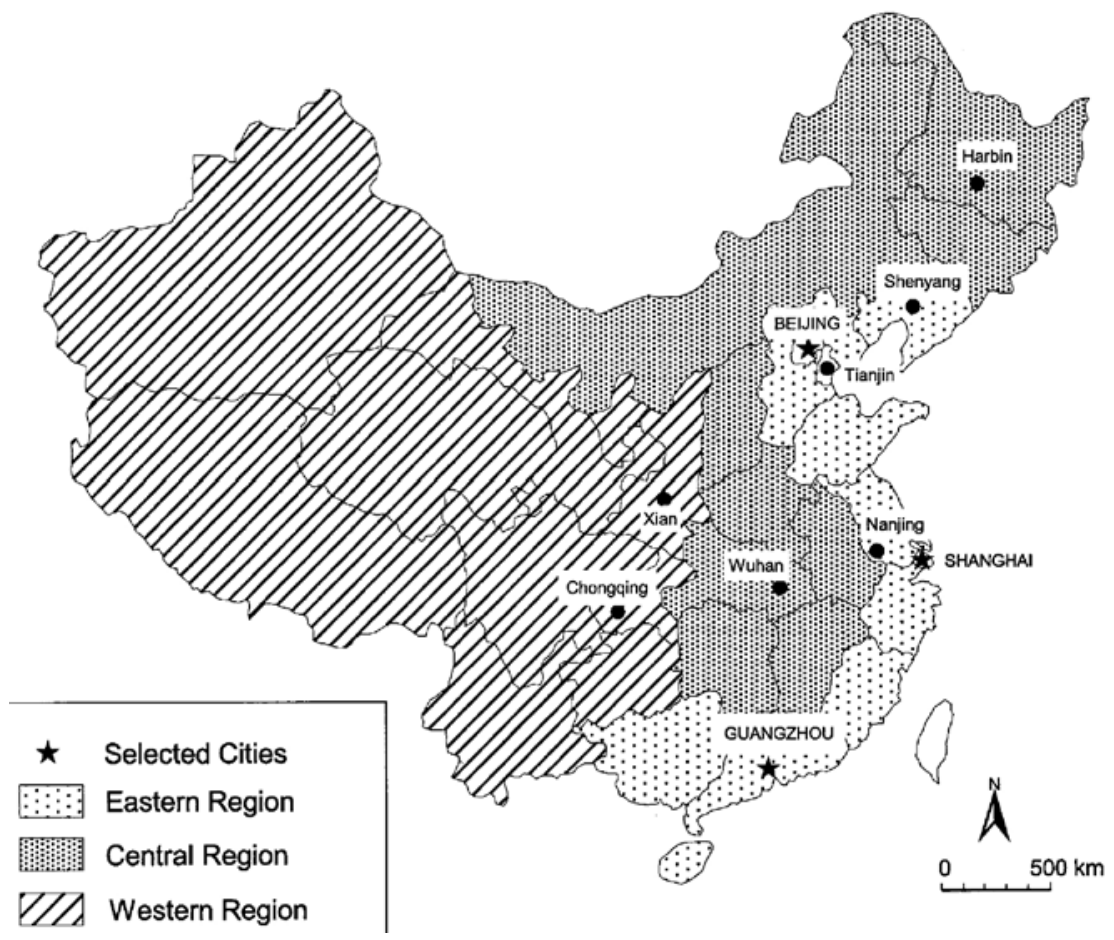

3. As transformações do espaço urbano na América Latina e em particular no Brasil

Nestor Canclini (2005), antropólogo argentino e professor da Universidade Autônoma Metropolitana do México, desenvolve uma instigante reflexão sobre o papel da cultura em cidades pouco sustentáveis, relevante para este trabalho. Diz, por exemplo, que nos últimos 50 anos as cidades latino-americanas viveram o crescimento mais acelerado de sua história, e que, nessa mudança de urbanização e industrialização, os políticos da região não estavam pensando 
nem preocupados com a problemática urbana. Canclini alarga ainda sua visão ao nos informar que também as ciências sociais começaram muito tardiamente a discutir o fenômeno urbano e cultural.

A população latino-americana tinha, na metade do século XX, uma distribuição igual entre campo e cidade. Hoje em dia, as urbes alcançam 80\% da população. Outro aspecto importante da reflexão do autor diz respeito ao descompasso entre o crescimento urbano de grandes metrópoles na região e as políticas de desenvolvimento que visavam à industrialização, sem maiores preocupações com os efeitos danosos das migrações internas que se amontoavam nas novas metrópoles. Este processo desencadeara a decomposição das cidades, inchadas pelo trabalho, pela exploração informal, pelo desemprego e pela violência do tráfico e da venda de armas. 0 antropólogo então se indaga de modo coerente: "Que pode significar a palavra sustentabilidade fora dos grandes fóruns internacionais, na vida cotidiana de cidades onde 20 a 30\% da população está desocupada e 50 a 70\% são pobres buscando sobreviver nos grandes centros?" (CANCLINI, 2005, p. 186).
Canclini (2005, p. 189) nos convida, assim, a repensar nossos estudos e planos urbanos nessa ampla dinâmica de fragmentação das cidades em que vivemos, onde o provisório acaba por tornar-se defınitivo. Os dados que indica são contundentes: em 1970, a população urbana da região era de 57,2\% e, já em 1995, atingia 73\%. Grosso modo, em 2005, a cifra aponta para 85\% do total.

Todo esse processo ganhou em velocidade no período neoliberal, pois a urbanização ocorreu sem planejamento, com normas frouxas ou incumpridas, e sofreu o desinvestimento público sistemático. 0 exemplo brasileiro é emblemático, quando no início dos anos 1980 é fechado o Banco nacional de Habitação (BNH). Em termos propriamente econômicos, a informalização, a precarização do mercado de trabalho e o subemprego, com repercussões nos baixos salários e na ausência de redes de proteção social, fızeram proliferar a favelização nos centros urbanos do país. Segundo estudos da CEPAL (Comissão Econômica para a América Latina), em 2002, mais de 70\% dos empregos criados na América Latina durante os anos 1990 eram do setor informal. 


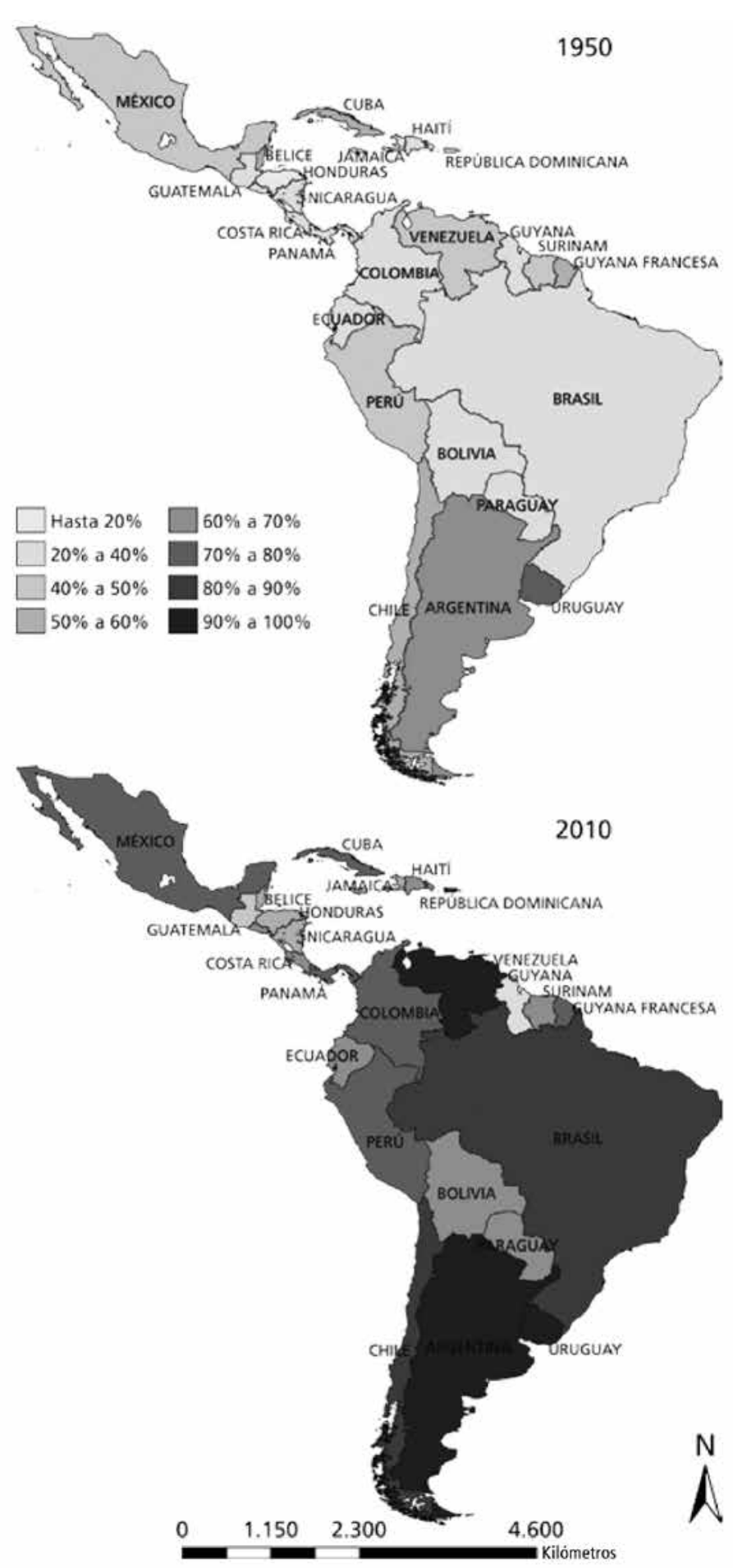


Pensar o urbano, a economia urbana hoje, nas grandes metrópoles periféricas exige grande abertura reflexiva, pois aqui, à diferença das metrópoles do $1^{\circ}$ Mundo, acumulam-se problemas de variada ordem, que vão do emprego à concentração de renda, à ineficiência ou mesmo ausência de serviços sociais indispensáveis de transporte, habitação, saúde, esgotamento sanitário, iluminação, áreas ver- des, água, poluição, entre outros, que são sistematicamente dramatizados por um padrão econômico que persiste em gerar satisfações e bem estar para fatias pequenas e privilegiadas; alternando taxas de crescimento em geral deprimidas por políticas macroeconômicas de altas taxas de juros, baixo investimento e favorecimento dos setores rentistas em detrimento da produção e do emprego formal.

Gráfico 3 - Taxa de urbanização e população urbana e rural: América Latina e Caribe

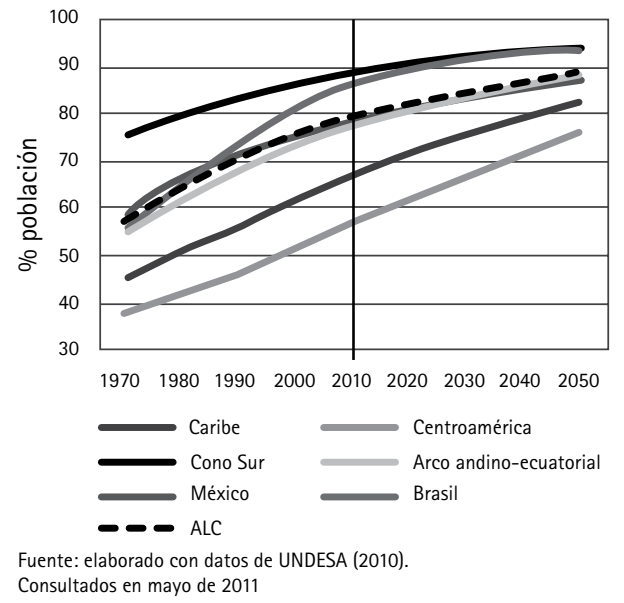

\section{0 caso urbano brasileiro}

No Brasil a recente discussão pública sobre o espaço urbano, as cidades e a dinâmica do sistema capitalista nos leva a observar o processo de urbanização por que passaram os grandes centros citadinos no país, principalmente do século passado aos dias atuais. A população brasileira saiu de uma condição eminentemente rural para constituir uma realidade preponderantemente urbana, num período de 40 anos, 1940 - 1980

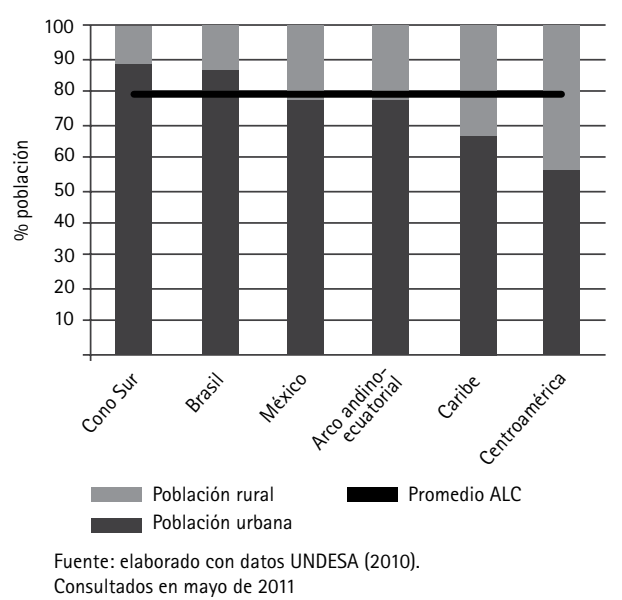

(Tabela 2). Segundo Maricato (2000; 2002; 2014), a partir da década de 1990 o forte processo de urbanização desacelera dando lugar ao que a pesquisadora chama de "tragédia urbana”. A urbanização no Brasil é percebida como um caminho para a modernização, entretanto tal processo (carregado de ambiguidades entre ruptura e continuidade) acaba por "recriar o atraso a partir de novas formas, como contraponto à dinâmica de modernização" (MARICATO, 2001) ${ }^{6}$.

6. “A dimensão da tragédia urbana brasileira está a exigir o desenvolvimento de respostas que devem partir do conhecimento da realidade empírica para evitar a formulação das 'ideias fora do lugar' tão características do planejamento urbano no Brasil” (MARICATO, 2001) 


\begin{tabular}{lllllllll}
\hline \multicolumn{7}{c}{ Ano } \\
Situação & 1940 & 1950 & 1960 & 1970 & 1980 & 1991 & 2000 & 2010 \\
Total & 41.236 & 51.944 & 70.992 & 94.509 & 121.151 & 146.825 & 169.799 & 190.755 \\
Urbana & 12.880 & 18.783 & 32.005 & 52.905 & 82.013 & 110.991 & 137.954 & 160.925 \\
Rural & 28.356 & 33.162 & 38.988 & 41.604 & 39.137 & 35.834 & 31.845 & 29.830 \\
& & \multicolumn{7}{c}{ Percentual (\%) } \\
Total & 100 & 100 & 100 & 100 & 100 & 100 & 100 & 100 \\
Urbana & 31,24 & 36,16 & 45,08 & 55,98 & 67,70 & 75,59 & 81,25 & 84,40 \\
Rural & 68,76 & 63,84 & 54,92 & 44,02 & 32,30 & 24,41 & 18,75 & 15,60 \\
& & & & & & & & \\
\hline
\end{tabular}

Fonte: Censos demográficos de 1940, 1950, 1960, 1970, 1980, 1991, 2000 e 2010, do Instituto Brasileiro de Geografia e Estatística (IBGE).

Nesse sentido, Maricato (2001) fez interessantes apontamentos históricos sobre as cidades brasileiras desde o final do século XIX, quando apenas 10\% da população encontrava-se nos centros urbanos:

O Brasil deixa o século XIX com aproximadamente $10 \%$ da população nas cidades (Santos, 1993). Considerando o universo das Américas, o Brasil já apresentava cidades de grande porte desde o período colonial, mas é somente a partir da virada do século XIX e das primeiras décadas do século XX que o processo de urbanização da sociedade começa realmente a se consolidar, impulsionado pela emergência do trabalhador livre, pela Proclamação da República e por uma indústria ainda incipiente que se desenrola na esteira das atividades ligadas à cafeicultura e às necessidades básicas do mercado interno.
As reformas urbanas [...] lançaram as bases de um urbanismo moderno à moda da periferia. Eram feitas obras de saneamento básico e embelezamento paisagístico, implantavamse as bases legais para um mercado imobiliário de corte capitalista, ao mesmo tempo em que a população excluída desse processo era expulsa para os morros e as franjas da cidade. (MARICATO, 2000, p. 21-22)

Maricato (2002) também aponta para três grandes fases do crescimento populacional urbano: a primeira ocorreu entre o final do século XIX e início do XX, quando é percebida "uma divisão territorial do trabalho extremamente marcada pelo setor primário e fortemente concentrado nos Estados de São Paulo, Rio de Janeiro e Minas Gerais"7; a segunda vai da década de 1930 e, de maneira acelerada, até a década de

7. Nessa fase inicial, Carvalho (2002) destaca algumas transformações relevantes nas cidades para a configuração do "mercado de trabalho urbano": 1) as mudanças referentes à progressão das forças produtivas, em especial a força de trabalho, provocadas por uma acentuada descontinuidade "entre as relações de produção predominantes, e a socialização do desenvolvimento das forças produtivas”, com destaque nos centros urbanos de São Paulo; 2) a transformação do Estado enquanto formulador de políticas públicas 
1970, com grande mobilização de mão de obra e de capitais associada a forte investimento público na consolidação dos sistemas de educação, saúde e previdência social, apesar dos esforços ainda serem focados na região Sudeste; por fim, a terceira fase, que tem início no final da década de 1970, é marcada por altíssimos índices de urbanização que, apesar de ainda concentrados nas mesmas regiões, já apresentam maior difusão entre outras capitais dos estados da federação e regiões metropolitanas, fazendo surgir um "imenso mercado de trabalho urbano".

0 modelo de desenvolvimento urbano do Brasil, com suas raízes no século XX, segundo aponta estudo do Instituto de Pesquisa Econômica Aplicada - IPEA (2011), usurpou das faixas de menor renda "condições básicas de urbanidade e de inserção efetiva à cidade”. Esta situação torna-se mais aguda no contexto da "tragédia urbana” (MARICATO, 2002), com o "boom" do fenômeno da favelização, da precarização de serviços de saneamento e infraestrutura urbana e da crise da mobilidade nos grandes centros urbanos. 0 modelo de espaços urbanos produzidos pelo processo de urbanização ocorrido foi concentrador no território, já que 60\% da população urbana vive em 224 municípios com mais de 100 mil habitantes, dos quais 94 pertencem às regiões metropolitanas com mais de um milhão de habitantes (IPEA, 2011).
Associadas à dinâmica da urbanização, destacam-se algumas outras variáveis que auxiliam na compreensão dos desdobramentos da dinâmica da "cidade corporativa e fragmentada" (SANTOS, 1994), tais como: exclusão socioespacial das favelas; crescimento demográfico e taxa de natalidade; concentração de renda ${ }^{8}$ e, consequentemente, desigualdade; e violência social; entre outras.

Todo esse processo aqui descrito, provocou o surgimento das chamadas "cidades médias" e de regiões metropolitanas na década de 1990. As cidades médias revelam uma face da nova configuração socioespacial das cidades brasileiras, num contexto de desconcentração industrial do país com implicações em políticas públicas. Tal contexto não é característico apenas do Brasil, mas também de países como Argentina, Chile, Colômbia e Peru (CARVALHO, 2002).

É possivel identificar uma tendência do processo de urbanização com concentração populacional em um número pequeno de cidades, afastando-se da centralidade das indústrias (SANTOS, 2010, 2011). As cidades médias são definidas comumente, entre vários parâmetros utilizados, como aquelas com população entre 100 e 500 mil habitantes, que não estão inseridas em regiões metropolitanas e que possuam um papel de grande relevância para a economia do país. Elas atuam como os principais centros industriais e de geração de emprego e influenciam na configuração do espaço.

urbanas e articulador e organizador do espaço urbano;3) novas formas de ocupação e moradia, como parte da expressão social, "impondo à classe trabalhadora alternativas de produção da habitação altamente mercantilizadas, bem como, outras alternativas de produção da habitação popular muito precárias, além dos cortiços ou da chamada auto-construção".

8. "Nas décadas de 80 e 90, a concentração de renda se aprofundou [...]. Não se trata simplesmente de uma desigualdade trazida pela reestruturação produtiva e pelo recuo das políticas sociais como sucede em muitos países centrais. Trata-se do aprofundamento da desigualdade numa sociedade historicamente e tradicionalmente desigual. [...] Nossas características nos tornaram modelo... de desigualdade social." (MARICATO, 2001) 
Segundo Santos (2011), o Brasil segue uma tendência surgida nos anos 1980 de polarização populacional urbana a partir das regiões metropolitanas. Porém, atualmente, são as cidades médias que direcionam esse processo de urbanização no país, com as mais altas taxas de crescimento urbano. Estas cidades estão se tornando elos mais importantes no processo de urbanização brasileiro pelas oportunidades de trabalho que criam.

Ainda de acordo com Santos (2011), o pequeno número de municípios, 283 (Ta- bela 2), com população superior a 100 mil habitantes $^{9}$ concentra elevado percentual da população $(54,75 \%)$ e da criação de empregos $(75,96 \%)$ no país. Nesse processo, as metrópoles se afirmam, mas as cidades médias ganham relevância como "centros regionais e articuladores do território”. É possível citar exemplos de cidades médias no Brasil: Caruaru (PE), Anápolis (G0), Imperatriz (MA), Ponta Grossa (PR), São José dos Campos (SP), Uberlândia (MG), entre outras.

Tabela 3 - Distribuição das cidades com mais de 100 mil habitantes, por macrorregiões econômicas, em 2010

\begin{tabular}{lllllll}
\hline Cidades/macrorregiões & Norte & Centro-oeste & Nordeste & Sudeste & Sul & Total \\
Capitais estaduais & 7 & 4 & 9 & 4 & 3 & 27 \\
CMM & 3 & 3 & 21 & 64 & 20 & 111 \\
CMN & 10 & 11 & 28 & 71 & 25 & 145 \\
Total & 20 & 18 & 58 & 139 & 48 & 283 \\
\end{tabular}

Fonte: Censo demográfico, 2010.

CMM (Cidades Médias Metropolitanas)

CMN (Cidades Médias Não-Metropolitanas)

Há uma tendência em curso desde a década de 1990 de que a indústria se desloque das grandes capitais e metrópoles para cidades de médio porte, ou seja, as metrópoles deixam de ser centros industriais passando essa tarefa para as cidades médias. Com isso, "aumenta a relevância das cidades médias como agentes do processo de descentralização das políticas públicas" (SANTOS, 2011, p. 2), tornando-se, assim, áreas de fluxos migratórios da população em busca de oportunidades de emprego em cidades onde o custo de vida seja inferior ao das metrópoles. Santos (2011) acredita que o aumento no número de cidades médias é um indicador de um movimento de "redistribuição espacial das oportunidades de trabalho", com destaque de que a maior parte das cidades médias brasileiras localiza-se na região Sudeste, segundo a Tabela 3, detentora também do maior PIB do país.

9. Incluindo as cidades médias metropolitanas. 


\begin{tabular}{lllllll}
\hline Anos/Regiões & Brasil (*) & Norte & Centro-oeste & Nordeste & Sudeste & Sul \\
2000 & 657.596 & 5,41 & 7,27 & 15,59 & 54,74 & 16,99 \\
2003 & 645.433 & 4,48 & 8,99 & 13,03 & 49,38 & 24,13 \\
2005 & 1.253 .981 & 3,89 & 4,45 & 15,71 & 63,01 & 12,94 \\
2007 & 1.617 .392 & 4,26 & 5,81 & 12,63 & 58,72 & 18,96 \\
2008 & 1.452 .204 & 1,83 & 7,32 & 14,02 & 57,86 & 18,96 \\
2009 & 995.110 & 3,74 & 7,05 & 22,85 & 47,84 & 18,52 \\
2010 & $2,136.947$ & 4,21 & 5,67 & 17,88 & 53,20 & 19,03 \\
(*) Em números absolutos & & & & & \\
\hline
\end{tabular}

Fonte: Elaboração própria com dados da CAGED/Ministério do Trabalho, 2000-2010.

Como aponta a tabela, houve elevação na criação de empregos a partir de 2003, com recuo em 2009 devido à crise financeira mundial voltando a crescer em 2010. Como aponta Santos (2011), as regiões Sul e Sudeste, as mais desenvolvidas do país, concentram quase $75 \%$ de toda a geração de empregos. Já entre as menos desenvolvidas, na região Norte houve redução na participação nos empregos; a região Nordeste alcançou expansão no mesmo quesito; e a região Centro-Oeste teve comportamento similar à região Norte.

Com isso, percebe-se que a "polarização espacial" 10 - devido ao setor de serviços e não mais às indústrias - do mercado de trabalho continua, mesmo diante da dinâmica da urbanização e suas transformações. Porém, é possível fazer alguns apontamentos: as regiões Sudeste e Sul, as mais ativas, apresentam desconcentração em direção às cidades médias, enquanto nas outras regiões as oportunidades de trabalho estão mais concentradas no perímetro metropolitano. Com isso, "o maior ativismo das políticas governamentais pode estimular a desconcentração dessas oportunidades de trabalho, mas sem alterar de forma significativa o maior peso das maiores metrópoles" (SANTOS, 2011).

\section{Considerações finais}

A dimensão que acabou tomando este artigo nos impossibilita de estabelecer uma conclusão mais dilatada. Cabe dizer, em primeiro lugar, que se trata de uma reflexão inicial, que terá desdobramentos. Em seguida, que o "caso chinês" analisado apresenta uma atividade intensa do Estado, de planejamento do desenvolvimento, onde as cidades constituem um elemento central para o amplo crescimento econômico, no qual estão articuladas as migrações campo-cidade, a infraestrutura de rodovias, de ferrovias e de mobilidade urbana, associadas a

10. Esse processo pode tornar as cidades no "lócus da crise social", como destaca Santos (2010, 2011) e, por isso, a questão urbana não deve ser resumida apenas ao provimento de moradia e serviços sociais; uma vez que seja preciso "providenciar respostas para pelo menos cinco novos desafios: trabalho e renda, segurança, integração sociocultural, sustentabilidade e governança”. 
um intenso processo de construção de imóveis para habitação e escolas, universidades, hospitais, parques e centros comerciais. 0 "modelo chinês" parece adotar a máxima de Glaeser (2011), segundo a qual a densidade urbana provê a via mais clara da pobreza para a prosperidade, como sendo a cidade a maior das invenções, porque articula a redução de custos através de economias de especialização e escala, propiciando maior velocidade na difusão do conhecimento e da informação.

No caso brasileiro, que não tem a dimensão das megalópoles chinesas - temos apenas três cidades com mais de 4 milhões de habitantes, quando a China tem mais de 25 nessa escala - vê-se que o planejamento do desenvolvimento foi abandonado no início dos anos 1980 e que o planejamento urbano foi deixado de lado. 0 processo migratório puxado pela industrialização foi avassalador e, ao mesmo tempo, sem regras. 0 fechamento do banco nacional de habitação no início desse período é emblemático. Ao contrário da China, fizemos a urbanização do país com um Estado incapaz de estabelecer as diretrizes balizadoras do crescimento. Daí a sensação de caos urbano que se verifica hoje nos grandes centros urbanos do Brasil.

\section{Referências}

ANDERSON, G.; GE, Ying. In: Regional Science and Urban Economics (35), 2005.

BAIROCH, P. Cities and economic development: from the dawn of history to the present (Christopher Braider, Trans.). Chicago: University of Chicago Press (Chinese version is translated by Xiao, Q. F. published at Nanchang: Jiangxi People's Press, 154, 247), 1988.

BARROS, J. D'A. Cidade e História. Petrópolis: Vozes, 2007.
BRAUDEL, F. L. V. In: Civilisation materièlle et Capitalisme. Tome Ier, Chapitre 8, 1967, p. 369-432.

BRUMES, K.R. Cidades: (Re) Definindo seus papeis ao longo da historia. Revista on line Caminhos de Geografia. 2 (3), março/2001, p.47-56.

CANCLINI, N. G. (2005), El papel de La cultura em lãs ciudades poco sustentables. In: Monica Allende Serra (Org.): Diversidad cultural y desarrollo urbano. São Paulo: Iluminuras, 2005, p.189:199.

CARVALHO, E. Cidades brasileiras, crescimento e desigualdade. Revista ORGCDEMO, $\mathrm{n}^{\circ} 3$, 2002, p. 45-54.

FOURQUET, F., Cidades e economias-mundo segundo Fernand Braudel. In: Espaço \& Debates, ano XI, $n^{\circ} 33,1991$, p.53:62.

GLAESER, E. The Triumph of the City. London: Penguim Books, 2011.

GU, C.; Wu, L.; Cook,L. Progress in research on chinese urbanization. Frontiers of Architecture Research 1(2), 2012, p.101-149.

HARVEY, D. A produção capitalista do espaço. São Paulo: Annablume, 2005.

Social justice and the city. Baltimore: Johns Hopkins, 1993.

IPEA. Brasil em Desenvolvimento: Estado, Planejamento e Políticas Públicas. v.1, p. 177200, 2011.

LEFEBVRE, H. A revolução urbana. Belo Horizonte: Ed. UFMG, 1999.

LI, X. e Liu, Y. Interpreting the hibridity of China's urbanization. Urban and Regional Planning, 4(3), 2011, p. 70-85.

MARICATO, E. Urbanismo na periferia do mundo globalizado: metrópoles brasileiras. São Paulo em Perspectiva, São Paulo, v. 14, $n^{\circ}$ 4, 2000.

Globalização e política urbana na periferia do capitalismo. In: RIBEIRO, L. C. Q; 
JUNIOR, 0. A. S. (Org.) As Metrópoles e a Questão Social Brasileira. Rio de Janeiro: Revan, 2007.

.Dimensões da tragédia urbana. In: http://www.comciencia.br/, 2002.

. Cidades no Brasil: neodesenvolvimentismo ou crescimento periférico predatório. Plataforma Política Social, 2014.

MARX. K. Contribuição à crítica da economia política. 2. ed., São Paulo: Expressão Popular, 2008.

O Capital: crítica da economia política. Livro I: o processo de produção do capital. São Paulo: Boitempo, 2013.

OLIVEIRA, F. Crítica à razão dualista. Rio de Janeiro: 1988.

ORDOVÁS, J.G. La cuestión urbana: algunas perspectivas críticas. In: Revista de Estudios Políticos (Nueva Época), nº 101, jul-set., 1998.

RIBEIRO, L. C. Q; JUNIOR, O. A. S. (Org.) "As Metrópoles e a Questão Social Brasileira”, Rio de Janeiro: Revan, 2007.

.Dimensões da tragédia urbana. In: http://www.comciencia.br/, 2002.

.Cidades no Brasil: neodesenvolvimentismo ou crescimento periférico predatório. Plataforma Política Social, 2014.

SANTOS, M. A urbanização brasileira. São Paulo: Hucitec, 1994.

Por uma economia política da cidade: o caso de São Paulo. 2. ed., São Paulo: Edusp, 2012.

SANTOS, A. M. S. P. Urbanização brasileira: um olhar sobre o papel das cidades médias na primeira década do século XXI. Revista Brasileira de Estudos Urbanos e Regionais v. 12, $\mathrm{n}^{\circ}$ 2, nov. 2010.

Cidades médias brasileiras: novas fronteiras de oportunidades. Apresentação em Seminário, agosto/ 2011.
STIGLITZ, J, A Nobel prize winner says: China is the biggest Keynesian State. In: Economy and Nation Weekly, april/2012.

WEI, Ye Hua Dennis, Restructuring for growth in urban china transitional institutions: Urban development and spatial transformation. In: Habitat International (36), 2012, p. 396-405.

ZHOU, S.; DAÍ, J. B. J., City size distribution in China: 1945 to 2010 and the impacts of government policies. New York, Elsevier, 2013. 


\section{RESUMO}

A questão urbana tem demandado de pesquisadores de diversas áreas intercessões no sentido de compreender os processos de formação das cidades para então, traçar possibilidades de modificação da realidade, principalmente onde o crescimento se deu de forma desordenada, com fragilidades ou mesmo ausência de planejamento. Este trabalho tem como proposta delinear um panorama geral, que se inicia com uma breve retrospectiva histórica dos processos de crescimento e desenvolvimento das cidades. $\mathrm{Na}$ segunda seção, apresenta-se o arcabouço teórico que auxilia na compreensão de aspectos atuais sobre o urbano. Para este intento, recorre-se ao pensamento de Henri Lefebvre, David Harvey e Manuel Castells, os quais, a partir de uma apropriação de categorias da Economia Política, incluem a noção de espaço no debate marxista. A terceira parte é composta por estudos específicos da realidade chinesa e brasileira. São observados os processos de urbanização das metrópoles na China e no Brasil, indicando a intensa atividade do Estado, com a centralidade do planejamento na articulação de infraestrutura para o país asiático e, em contraposição, o crescimento desordenado e o abandono do planejamento urbano que se observa no caso brasileiro.

\section{PALAVRAS-CHAVE}

Território. Cidades. Desenvolvimento. Brasil. China.

\section{ABSTRACT}

The urban question has required from researchers from diverse fields intercessions in order to understand the processes of formation of cities and then trace modification possibilities of reality, especially where growth occurred in a disorderly manner, with weaknesses or lack of planning. This paper aims to outline an overview, which begins with a brief historical overview of the processes of growth and development of cities. The second section presents the theoretical framework that helps to understand the current features on urban. For this purpose, we resort to the thought of Henri Lefebvre, David Harvey and Manuel Castells, who, from an appropriation of categories of political economy, includes the notion of space in the Marxist debate. The third part consists of specific studies of Chinese and Brazilian reality. Processes of urbanization of cities in China and Brazil are observed, indicating the intense activity of the State, with the centrality of in the articulation planning of infrastructure for the Asian country, and in contrast, the disordered growth and abandonment of urban planning that observed in the Brazilian case.

\section{KEYWORDS}

Territory. Cities. Development. Brazil. China. 